\title{
Computers and Internet Related Beliefs among Estonian Computer Users and Non-Users
}

\author{
Pille Pruulmann-Vengerfeldt \\ University of Tartu, Department of Journalism and communications \\ pille.vengerfeldt@ut.ee,http://www.jrn.ut.ee/
}

\begin{abstract}
This paper aims to look at the computer and Internet related beliefs among Estonian computer users and non-users. It uses data from two nationally representative surveys to analyze seven Internet and computer related beliefs. The paper also discusses how understanding the opinions of computer users and non-users should influence the policies of the information society. As a conclusion, policy suggestions on visibility of the technologies, digital literacy, and data monitoring needs are made.
\end{abstract}

Keywords: technology related beliefs, computer users and non-users, information society policy, adaptive theory.

\section{Introduction}

As new technologies emerge and constantly outdate each other, it is difficult to imagine that only less than fifteen years ago, there was no Internet connection in Estonia and that computers were highly specialized tools kept in labs. No one thought that usage and distribution of these technologies might become an important part of the notion of information society. Yet, nowadays, it is hard to imagine anyone living in Estonia who has not heard about these technologies. The Estonian case in interesting because of the simultaneous co-occurrence of several 'revolutions', alongside with the 'singing revolution' contributing to the political collapse of the Soviet Union, Estonia witnessed a rapid turn towards capitalism and market economy. At the same time, international 'technology revolution' also reached Estonia and flooded society with options and possibilities that were very positively received.

The aim of this paper is to look at the context of Estonian information and technology developments from the perspective of social informatics. Social

\footnotetext{
Please use the following format when citing this chapter:

Pruulmann-Vengerfeldt, P, 2006, in IFIP International Federation for Information Processing, Volume 223, Social Informatics: An Information Society for All? In Remembrance of Rob Kling, eds. Berleur, J., Numinen, M. I., Impagliazzo, J., (Boston: Springer), pp. $459-468$.
} 
informatics has several different aspects - micro level of design and uses and macro level of institutions and societies. It also has many disciplinary backgrounds and as Rob Kling [1] puts it: "It is a field that is defined by its topic rather than family of methods". Diversity of the disciplines and ever-expanding research objects makes social informatics somewhat difficult to comprehend; yet we need to learn many valuable lessons.

The aim of this paper is to look at the computers and Internet related beliefs of the Estonian people and draw some policy conclusions from this material.

\section{Theoretical Context and Focus of the Study}

One of the major problems with technology research is that it either is overpowered by political assumptions or hopes nicely referred as punditry [1] or that they are very empirical and lack theorization. Social informatics has been building the body of research over twenty-five years and has connected the ideas of empirical and theoretical research.

Derek Layder [2] is one of those who seek an answer on how to connect theoretical and empirical work. In his opinion, social theory often lacks the connection between well-grounded empirical research and more theoretical approaches. He proposes a notion of adaptive theory.

"The word 'adaptive' is meant to convey that the theory both adapts to, or is shaped by, incoming evidence while the data itself is simultaneously filtered through, and is thus adapted by, the prior theoretical materials (frameworks, concepts, ideas) that are relevant to their analysis"[3].

This paper tries to follow the ideas of the adaptive theory by first providing a conceptual framework for the data, by using the notions of social informatics and information environment. In the second half of the paper I will analyze the data with the help of the questions that social informatics asks and provide some policy suggestions. We can consider social informatics to be a very good example of what Layder considers as adaptive theory, as it is constantly revising itself in the face of the empirical material provided.

Social informatics has used the methods of the adaptive theory to help empirical material to understand better and often to overthrow some of the everyday beliefs that have received the status of theories, like for instance the direct effect theories [4]. One of the key aspects of the social informatics is to find and to stress the importance of the socio-technical character of the information technologies. The present study will investigate one aspect of the socio-technical network, namely people and their beliefs. We will look at the everyday understanding of the state of the information society in Estonia and the way it has changed in the years of 20022005.

Beliefs and attitudes are expressions of the human emotional disposition, subjective preferences and goals [5]. Beliefs are communicated through interpersonal communication or media; they can be acquired also though individual contemplation. Beliefs and attitudes do not guarantee behavior in desired direction, but rather reflect the overall disposition towards the topic. Therefore, we cannot 
conclude that positive beliefs will result in positive behavior. Investigation of computer and technology related beliefs shows a more general public opinion and helps to understand the cultural context of the technology adoption.

\section{Focus on the Information Environment}

Estonia is one of the fastest developing countries in Europe in the late 1990s. Its speedy developments in the field of electronic governance and Internet in schools has influenced Estonian people. The general understandings of the technological developments have been supportive and that understanding has spread to individual use of the new technologies. Although the Internet adoption rates are not as good as in neighboring countries such as Finland and Sweden, they are significantly higher than in other Baltic states [6]. That advantage has also supported Estonian's selfimage as active and technology-savvy country.

There have been many discussions as to what contributes to such rapid developments. Estonian society has been welcoming different initiatives with open arms. Hence, the aim of this article is to look at one of the possible reasons as to why ICTs have been so popular in Estonia. There are number of different explanations as to what contributes to the social environment that is so encouraging for the take-up of new information technologies.

Social informatics helps us in asking the question about the cultural context of specific adoption process. Leah Lievrouw [7] in her article about knowledge dissemination in society defines information environments as social settings or milieu in which these resources, relations and technologies undergo a structurationtype process of change called informing. In her schematic model, she divides the environment into "an institutional aspect and a personal/relational aspect, which are closely related and interact" [8]. Looking at those different aspects of information environment enables us to locate a variety of factors that influence ICTs dissemination in culture-specific contexts. Government, businesses, and media provide the institutional aspect; individual beliefs, values and understandings as well as social networks like family, kin, and workmates constitute the personal/relational aspect. They are strongly influenced by one another and therefore very complex to research. From these different factors, this article focuses on the technology related opinions among Estonian computer users and non-users. Their beliefs provide one measurable aspect of the social and cultural context in which the adoption of new technologies takes place. It is important to understand that the technology adoption is not a once-off experience, but rather a repetitive cycle where each new application of the same, already adopted technology, needs to be re-adopted continuously. Beliefs and understandings form an important background for such a process.

I am going to compare the different opinions and attitudes among computer users and non-users. I think this is an important step in understanding the notion of human choice in computer and Internet adoption as our opinions and beliefs strongly govern the way we behave. This paper is part of a larger study that uses longitudinal data to investigate Estonian people at the wake of the $21^{\text {st }}$ century. Data gathered within this project is versatile and covers many areas of people's everyday life, media use, values, beliefs, relation to money, politics, culture, and to other people [9]. This 
paper only manages to introduce very few of the issues covered - namely Internet and computers related beliefs, but I think they are very important ones to be considered when talking about the social and cultural context of the particular adoption.

\section{Method}

I will look at data from two representative longitudinal surveys conducted in Estonia - in late 2002 and early 2003 and late 2005 . The survey was conducted in Estonia, with the representative sample of 1470 people in 2003 and 1475 in 2005 . We collected data with a written questionnaire complemented by an oral interview. Interviewers left the respondents the survey booklet containing about 700 questions. In addition to that, interviewers agreed time to meet with the respondents, collect the questionnaire and ask additional 80 questions from those who qualified for the oral interview. The survey was conducted in 150 survey points across Estonia with the 'youngest male method' where interviewers asked to speak with the youngest male member of the household and if he was not present, the youngest female was asked to participate. The survey was conducted within the age group of 15-74 and 500 of the respondents were Russian speakers (for more detailed information about the study see Kalmus, Lauristin, Pruulmann-Vengerfeldt [9]).

For the present paper, the following question asked from the respondents is most relevant: With computers and Internet becoming a part of everyday life, there are many opinions about them. Hereby we provide you a list of some of those opinions that have been circulating about computers and Internet. To which extent do you agree with them? The following options were given: 'agree completely', 'agree to a certain extent', 'disagree to a certain extent', 'disagree completely', and 'I don't know, don't have an opinion' were given. In 2003, there were fourteen and in 2005 , there were twenty statements in the survey. For the present analysis, I have divided the answers into three subsets: complete and partial agreements, complete and partial disagreements, and no opinion. I have selected seven variables that are comparable between the years and that $I$ consider more related to the computer and Internet adoption rates.

I will compare the answers of users and non-users of the computers as well as compare different years. For the purpose of this study, I define computer users as those who answered 'Yes' to the following question: 'Do you use a computer?' We asked the question with no specific definition of the use and without a timeframe, which leaves the definition of the use up to the respondent.

Statements that are under investigation cover both computer and Internet use, but the variable we compare them against is only computer use. This is because the number of people who use computers, but do not use the Internet is relatively small in our sample. In $2003,48 \%$ of the respondents were computer users and $90 \%$ of them were Internet users. In 2005 , the level of computer usage has risen to $68,5 \%$ of respondents, and the level of Internet usage has risen to $94 \%$ of the computer users. As the computer-use variable was used as the gatekeeper variable to the Internet use question, then there is no information about those people who would say that they 
are Internet users without actually defining themselves as computer users. We have assumed that the number of those people is very marginal.

\section{Internet Related Beliefs and Opinions in Empirical Material}

In Table 1, we have gathered information about seven statements that we asked the computer users and non-users to rate.

Table 1: Internet and computer related opinions of the computer users and non-users in Estonia, in 2003 and 2005

\begin{tabular}{|c|c|c|c|c|c|}
\hline Statement & Year & $\begin{array}{l}\text { Computer } \\
\text { use/non-use }\end{array}$ & $\begin{array}{l}\text { Agreement } \\
\text { with the } \\
\text { statement }\end{array}$ & $\begin{array}{l}\text { Disagreement } \\
\text { with the } \\
\text { statement }\end{array}$ & $\begin{array}{l}\text { Uncertain, } \\
\text { don't know }\end{array}$ \\
\hline \multirow{8}{*}{$\begin{array}{l}\text { Frequent use of } \\
\text { computers and the } \\
\text { Internet is not good } \\
\text { for your health } \\
\text { The Internet makes } \\
\text { people to waste work } \\
\text { and study time }\end{array}$} & \multirow[t]{2}{*}{2003} & User & $53 \%$ & $37 \%$ & $10 \%$ \\
\hline & & Non-user & $59 \%$ & $12 \%$ & $29 \%$ \\
\hline & \multirow[t]{2}{*}{2005} & User & $56 \%$ & $37 \%$ & $6 \%$ \\
\hline & & Non-user & $58 \%$ & $8 \%$ & $27 \%$ \\
\hline & \multirow[t]{2}{*}{2003} & User & $35 \%$ & $60 \%$ & $5 \%$ \\
\hline & & Non-user & $31 \%$ & $38 \%$ & $30 \%$ \\
\hline & \multirow[t]{2}{*}{2005} & User & $38 \%$ & $56 \%$ & $5 \%$ \\
\hline & & Non-user & $39 \%$ & $33 \%$ & $21 \%$ \\
\hline \multirow{4}{*}{$\begin{array}{l}\text { The Internet enables } \\
\text { citizens to influence } \\
\text { politics more }\end{array}$} & \multirow[t]{2}{*}{2003} & User & $25 \%$ & $55 \%$ & $20 \%$ \\
\hline & & Non-user & $14 \%$ & $40 \%$ & $46 \%$ \\
\hline & \multirow[t]{2}{*}{2005} & User & $17 \%$ & $64 \%$ & $17 \%$ \\
\hline & & Non-user & $13 \%$ & $41 \%$ & $40 \%$ \\
\hline \multirow{4}{*}{$\begin{array}{l}\text { The Internet alienates } \\
\text { people from each } \\
\text { other }\end{array}$} & \multirow[t]{2}{*}{2003} & User & $36 \%$ & $54 \%$ & $10 \%$ \\
\hline & & Non-user & $41 \%$ & $23 \%$ & $36 \%$ \\
\hline & \multirow[t]{2}{*}{2005} & User & $46 \%$ & $45 \%$ & $8 \%$ \\
\hline & & Non-user & $42 \%$ & $23 \%$ & $28 \%$ \\
\hline \multirow{4}{*}{$\begin{array}{l}\text { Using computers and } \\
\text { the Internet scares } \\
\text { me }\end{array}$} & \multirow[t]{2}{*}{2003} & User & $5 \%$ & $89 \%$ & $6 \%$ \\
\hline & & Non-user & $17 \%$ & $49 \%$ & $34 \%$ \\
\hline & \multirow[t]{2}{*}{2005} & User & $9 \%$ & $83 \%$ & $7 \%$ \\
\hline & & Non-user & $19 \%$ & $37 \%$ & $35 \%$ \\
\hline \multirow{4}{*}{$\begin{array}{l}\text { All children must } \\
\text { have the possibility } \\
\text { to use computers and } \\
\text { the Internet as early } \\
\text { as possible }\end{array}$} & \multirow[t]{2}{*}{2003} & User & $71 \%$ & $24 \%$ & $5 \%$ \\
\hline & & Non-user & $64 \%$ & $23 \%$ & $14 \%$ \\
\hline & \multirow[t]{2}{*}{2005} & User & $46 \%$ & $45 \%$ & $8 \%$ \\
\hline & & Non-user & $37 \%$ & $36 \%$ & $20 \%$ \\
\hline All people who don't & \multirow[t]{2}{*}{2003} & User & $54 \%$ & $39 \%$ & $8 \%$ \\
\hline have access to the & & Non-user & $50 \%$ & $28 \%$ & $22 \%$ \\
\hline Internet are & \multirow[t]{2}{*}{2005} & User & $53 \%$ & $38 \%$ & $8 \%$ \\
\hline $\begin{array}{l}\text { disadvantaged in all } \\
\text { aspects of life }\end{array}$ & & Non-user & $35 \%$ & $37 \%$ & $20 \%$ \\
\hline
\end{tabular}

The most significant difference between the users and non-users are that besides being more positive and optimistic about the Internet and computers, in general, 
computer users are more opinionated. The number of computer non-users, who do not have an opinion about the statements, is remarkably larger than the proportion of computer users who are unsure about the given statement.

These statements demonstrate the positive attitudes prevailing among the Estonian public. I will now discuss each of those statements separately.

Connection between Internet or computer use with health issues is very common in everyday discourses in Estonia. People are mostly worried about their eyesight, but sedentary lifestyle of computer users is also an issue. Very common is the understanding that children who are using computers are not interested in participating in sports. Also in our sample, more than half of the people agree with the idea that frequent computer use may not be good for your health. The opinions about this statement show that more computer users have became to agree with that statement.

Wasting time with computers has been one of the negative attitudes among general optimism. We expected a rise in productivity, although social informatics studies elsewhere are not supporting this optimism [1]. Similarly in Estonia, people, who originally placed much hope on computers diminishing the workload and increasing productivity, found that people could do so many things with computers and the Internet. People tend to start dividing their attentions and not concentrating on the issues of work alone. Results from the survey show that more than half of the computer users disagree with the idea that computers make you waste the time. The number of non-users who disagree with the statement has decreased over the years. The concept that new technologies are adopted in the context of the existing lifestyle is not new. Non-users who feel that meaningful activities fill their lives, they fear that using computers may make them waste the time they have now for other things like reading and spending time with the family. However, the levels of being uncertain about this issue have decreased quite significantly among the non-users, indicating that people who have remained non-users are more sure in their opinion whether ICTs are waste of time or not.

The next statement is strongly connected with the optimistic hopes that people have had towards the technology. Estonia's e-government is a very successful project that received much attention. For instance, Network Readiness Index has rated Estonia to the $5^{\text {th }}$ place in e-governance index in 2001 and to the $8^{\text {th }}$ place in egovernance index in 2002 [10]. Estonia has also a digital democracy project called Today I Decide (TOM in Estonian) that received much media attention at the time of its creation in June 2001. It is possible to see disappointment of the computer users in this system - the number of computer users who believe that Internet enables citizens to influence politics has dropped and the number of those who disagree with the statement has risen.

Discussion that has received a lot of attention from social scientists is the issue of alienation and social capital of the Internet users [11, 12]. Different reactions have made this issue to be on the top of the Internet related agenda for quite some time. The data reveals that in 2003 more than half of the people who used computers did not believe that computers cause alienation, but in 2005 , the percent has dropped below half. At this point, it is difficult to say what causes this: changed opinions, changed experiences, or enlarged user-body are probably all part of the explanation. 
A number of people are hesitant to adopt new technologies because they are scared of them. People might be afraid of the consequences of technology adoption or fear that they look stupid or that they might break something. In our sample, it is interesting to see that the number of people who are afraid of using ICTs has risen among the computer users and declined among the non-users. It may be that the pressures in the society to apply new technologies are so remarkable that people are adopting them in spite of their fears and use of the technology has not made them overcome their fears

In recent years the debate of computer addiction and children has became livelier in Estonia. The result is that $73 \%$ of the population thinks that children's computer addiction has become a serious problem. The replies to the question of whether children must have early contact with the computers also reflect this. The percentages of people who agree with this statement have declined among the computer users and the non-users.

In spite of the pessimistic and cautious beliefs, more than half of the computer users believe that people who don't have access to the Internet are disadvantaged in their life. The number of non-users who believe the same thing has decreased and partially probably because they are computer users now.

With the negative statements, the health related statement is the only one where more than half of the people agree with it, be they computer users or not. All other negative statements have less than half of the population supporting them. On the other hand, the positive statements receive also less than half of the population's support. It shows there is overwhelming agreement does not exist with either positive or negative attitudes. However, in general, computer users are more inclined to have positive beliefs towards the information and communication technologies, whereas non-users have more people among them who are uncertain.

\section{Implications for the Information Policy of Estonia}

Most of the statements under investigation here are common day-to-day statements that circulate between people, in public and private texts. It seems that although people sometimes consider Estonia very optimistic and positive in attitudes towards the Internet and computers $[13,14]$, the data indicates that the optimism is not so overwhelming. There are several policy lessons we can learn from these findings.

Without wanting to go too deeply into policy analysis, I would still like to draw a few conclusions from the current study that the Estonian information society policy could find useful. Estonia is currently in the process of formulating new principles in the information society policy for the years $2007-2010$. This is the first policy document where active involvement of the researchers has been encouraged and enabled. Previous policies have been technology and economic centred $[15,16]$ whereas there is a strong possibility that the policy document under construction will also consider human and social aspects of the new technologies.

Firstly, we consider a lesson that is strongly connected to Roger's [17] theories about diffusion of innovations. It is clear that information about the innovation is very important. The fact that approximately one fifth of the non-users doesn't have 
an opinion about the statements that were provided shows that there is still not enough information, not enough possibilities to observe other people using information and communication technologies. If information policy-makers are interested in influencing the human choice towards adopting new technologies and government-provided services in new media environment, they must foster a wellbalanced and open information environment.

Today, the ICTs related information provided by the government is hectic and inconsistent. It is also not focusing on the day-to-day usage by the individuals, thus not providing the necessary observation moment for the non-users. There are different possibilities for local or state government to promote their own services in a way where use of those services can be observed publicly and therefore people would be more inclined to try themselves. However, the indifference towards a technology might mean that people generally ignore the public messages about technology related activities and might therefore be more difficult to reach. For them, the educational aspects of the information environment may be available through the personal aspects of their information environment where friends and relatives can become proxies for mediating the ICTs related information provided by different institutions.

Second, a policy lesson that can be learned is that the issue of young children's use of computers and Internet is something that needs even wider public discussion and probably some political decisions. Children seem at risk from computers and Internet and often parents even do not know how to help them. Information society policy should acknowledge the concern and find ways to support parents in their attempts to regulate children's exposure to new information and communication technologies. Thus, information society for all needs clear political activities to provide digital literacy not only in a way to be able to use technologies, but also to interpret the content accessed by those technologies in a safe way. The role of the policy makers is to make sure that digital literacy skills are included in the school programmes and that they are meaningful and helpful for all different levels of user competences and abilities.

Another idea that can be taken to policies outside Estonia is that monitoring these kinds of opinions and understandings through surveys can help to see how they are changing, what is on agenda and what concerns people have in relation to the technology. The set-up of the current study was the following - for the first questionnaire we devised our questions based on an international survey (World Internet Project [18]) and modified them to suit our survey In 2005, however, we took the same questions, removed some that had vague wording and added new ones that we had derived from media analysis. Media, especially traditional media that is most popular for that particular cultural context, is an important source for information in today's 'mediatised' world and sometimes it seems that computer and Internet studies do not pay enough attention to the content of 'old' media. At least in Estonia, where for instance newspaper readership is relatively high, the press is a very important shaper of the public opinion. 


\section{Conclusion}

Researching the Internet and computer related beliefs and opinions, gives an important insight into human choice and ICTs. It shows some underlying principles that people use in their decision making whether to adopt new technologies or not. The more complex the technology under investigation, the more important the issue of knowledge about the innovation becomes. In order to understand the human choice in the question of information technology adoptions, understanding attitudes towards the common beliefs related to that technology is a first step. The complexity of the information environment exposed to modern people is too large to address in only one paper. This study is only part of a larger project that investigates the different aspects of the institutional and personal information environment.

There are several policy lessons that we can learn from the study, mostly showing the key aspects of the concern by the public, but also helping to understand the factors underlying the decisions people make in relation to the information technologies. Today, data about the beliefs in the different countries is relatively difficult to access and probably not available at all in many cases. However, knowing the stronger currents in public opinion related to information and communication technologies would make the information society more accessible and understandable for all. Having material for international comparison would give better understanding of the different factors in shaping the social and cultural context of the particular technologies adoption.

Social informatics is a good example of adaptive theory that helps us to understand that empirical research, theoretical generalizations, and policy lessons are all strongly interconnected; we cannot and should not consider them in isolation.

\section{References}

1. R. Kling, What is social informatics and why does it matter? D-lib Magazine 5(1) (1999), http://www.dlib.org/dlib/january99/kling/01kling.html (Last accessed 30/03/2006)

2. D. Layder, Sociological Practice: linking theory and social research, (Sage, London, Thousand Oaks, New Delhi, 1998)

3. Ibid., pp.5.

4. R. Kling, H. Crawford, H. Rosenbaum, S. Sawyer and S. Weisband, Learning from Social Informatics: information and communication technologies in human contexts, (Centre for Social Informatics, Indiana University, 2000), http://rkcsi.indiana.edu/media/SI_report.pdf (Last accessed 30/03/2006)

5. M. Lauristin and P. Vihalemm, Massikommunikatsiooni teooria: õppevahend_urnalistika üliõpilastele, Tartu Riiklik Ülikool, Tartu, 1977.

6. M. Bogdanowicz, J. Burgelman, C. Centeno, E. Gourova and G. Carat, Factors of regional/national success in information society developments: Information society strategies for candidate countries, First Monday 8(10) (2003), http://www.firstmonday.org/issues/issue8_10/ (Last accessed 30/03/2006)

7. L. Lievrouw, New media and the 'pluralization of life-worlds': a role for information in social differentiation, New Media and Society 3(1), 7-28 (2001) pp.12

8. Ibid., pp. 13 
9. V. Kalmus, M. Lauristin, P. Pruulmann-Vengerfeldt, Eesti elavik 21. sajandi algul: ülevaade uurimuse Mina. Maailm. Meedia tulemustest, Univeristy of Tartu Press, Tartu, 2004.

10. P. Vengerfeldt, and P. Runnel, Uus meedia Eestis in: Meedia süsteem ja meediakasutus Eestis 1965-2004, edited by P. Vihalemm, University of Tartu Press, Tartu, 2004, pp. 233-256.

11. A. Quan-Haase, B. Wellman, J. C. Witte and K. N. Hampton, Capitalizing on the Net: social contact, civic engagement and sense of community, in: The Internet in Everyday life, edited by B. Wellman and C. Haythornthwaite, Blackwell Publishing, Malden, 2002 pp. 291-324.

12. J. Boase, J. B. Horrigan, B. Wellman and L. Rainie, The Strength of Internet Ties The Internet and email aid users in maintaining their social networks and provide pathways to help when people face big decisions (Pew Internet and American Life Project, Washington, 2006), http://www.pewinternet.org/pdfs/PIP_internet_ties.pdf (Last accessed 30/03/2006).

13. Accenture, Markel foundation and UNDP, Creating a development dynamic: Final report of the Digital Opportunity Initiative (2001)

http://www.opt-init.org/framework/pages/contents.html (Last accessed 30/03/2006).

14. Lander, M, Hot technology for chilly streets in Estonia, New York Times (13/12/2005).

15. Information policy principles for 2002-2003, http://www.riso.ee/en/informationpolicy/policy-document (Last accessed 30/03/2006).

16. Information policy for 2004-2006, http://www.riso.ee/en/files/Policy.pdf (Last accessed 30/03/2006).

17. E. Rogers, Diffusion of innovations, Free Press, New York, 1995

18. The World Internet Project, http://www.worldinternetporject.net, (Last accessed $30 / / 03 / 2006$ ). 